УДК 378.01

DOI: 10.37026/2520-6427-2020-103-3-131-135
Віталій ДОНЕЦЬ,

директор Державної реабілітаиійної установи «Центр комплексної реабілітації

для дітей з інвалідністю «Промінь», м. Вінниця

\title{
ФОРМУВАННЯ ГОТОВНОСТІ ДО ІННОВАЦІЙНОЇ ДІЯЛЬНОСТІ ВЧИТЕЛІВ ПОЧАТКОВИХ КЛАСІВ В УМОВАХ ІНКЛЮЗЇ̈ У ПРОЦЕСІ ФАХОВОЇ ДІЯЛЬНОСТІ
}

\begin{abstract}
Стаття присвячена науковому пошуку шляхів формування готовності вчителів початкової школи до інновачійної діяльності в умовах інклюзивного навчання. Обгрунтовано методичні особливості формування готовності до інновачійної діяльності вчителів початкової школи в умовах науково-методичної роботи закладу загальної середньої освіти. Розроблено модель формування готовності до інновачійної діяльності вчителів початкової школи в умовах інклюзивного навчання, у процесі педагогічного експерименту перевірено дієвість запропонованих інновачій та одержано підтвердження ефрективності представленої моделі. Доведено, щзо необхідність иілеспрямованого впливу на розвиток готовності вчителів до провадження інноваційної діяльності в умовах інклюзивного навчання позитивно впливатиме на рівень їхньої фахової компетентності.
\end{abstract}

Ключові слова: інноваційна діяльність, готовність до інновачійної діяльності, інклюзивне навчання, заклади загальної середньої освіти, вчителі початкової иколи, педагогічний експеримент.

Статья посвящена научному почску путей формирования готовности учителей начальной школьг к инновационной деятельности в условиях инклюзивного обучения. Обоснованы методические особенности формирования готовности к инновационной деятельности учителей начальной школь в условиях научно-методической работь заведения общего среднего образования. Разработана модель формирования готовности к инновационной деятельности учителей начальной школьг в условиях инклюзивного обучения, в прочессе педагогического эксперимента проверена действенность предложенных инноваций и получено подтверждение эффективности представленной модели. Доказано, что необходимость иеленаправленного влияния на развитие готовности учителей к осуществлению инновационной деятельности в условиях инклюзивного обучения положительно влияет на уровень их профессиональной компетентности.

Ключевые слова: инновачионная деятельность, готовность к инновачионной деятельности, инклюзивное обучение, заведения общего среднего образования, учителя начальной школь, педагогический эксперимент.
The article is devoted to the scientific search for ways to form the readiness of primary school teachers to innovate activity in the conditions of inclusive education. According to the results of the analysis of scientific and methodical developments on the problem of research and generalization of own experience, the methodical features of readiness formation for innovative activity of primary school teachers in the conditions of scientific and methodical work of general educational institution were substantiated.

According to the results of the study of the problems dealing with preparation of specialists for the work in the conditions of inclusive education, the conclusion was made that working teachers have certain difficulties in improving the skills of professional activity in the conditions of inclusive education. This is shown by the fact that currently, according to expert assessment, the provision of methodical materials of primary school to work in the conditions of inclusive education does not exceed $30 \%$, low motivation of teachers to implement the inclusive education, both due to the intensity and diffculty of work and misunderstanding of the peculiarities of the work in the conditions of the inclusive education inclusion.

In the process of pedagogical experiment, the effectiveness of the proposed innovations was tested and the effectiveness of the developed model of the readiness formation for the innovative activities of primary school teachers in the conditions of inclusive education was confirmed. The use of Fisher's angular criterion to assess the results of the experiment allowed us to make a conclusion that there is a significant statistical difference in the levels of readiness of primary school teachers to innovation activity in the conditions of the inclusive education, which indicates the need for the targeted impact on teachers' readiness to the introduction of innovation activity in the conditions of the inclusive education that will positively affect the level of professional competence.

Key words: innovative activity, readiness for innovative activity, inclusive education, institutions of general secondary education, primary school teachers, pedagogical experiment. 
Постановка проблеми. На сучасному етапі розвитку освіти відбуваються кардинальні зміни у системі безперервної підготовки фахівців, зокрема й тих, які будуть долучені до роботи 3 дітьми з особливими освітніми потребами. Проблеми формування професійної компетентності фахівців, які працюють в системі інклюзивної освіти пов'язані 3 наявністю суттєвих вимог, висунутих суспільством до такої педагогічної діяльності. Відповідно це передбачає необхідність постійного наукового пошуку шляхів і засобів професійного вдосконалення вчителів, орієнтації кожного фахівця на неперервне професійне зростання тощо.

Таким чином, упровадження інноваційних технологій у освітній процес закладів загальної середньої освіти є необхідністю, викликаною динамічним розвитком суспільства. Зважаючи на це, постає завдання розробки відповідного методичного забезпечення щодо здійснення вчителями початкової школи інноваційної діяльності в умовах інклюзивного навчання.

Аналіз наукових досліджень і публікацій. Питання провадження інноваційної педагогічної діяльності розглядалися в працях I. Беха, I. Дичківської, Л. Жиле, О. Пєхоти, О. Попової, Л. Подимової, А. Прігожина, В. Сластьоніна та ін. Проблеми організації навчального процесу із включенням до нього дітей з особливими освітніми потребами розглядали О. Волошина, Т. Свтухова, А. Капська, В. Ляшенко, О. Столяренко, П. Таланчук, В. Тесленко, І. Холковська, А. Шевцов та ін. Питання підготовки фахівців до роботи в умовах інклюзивного навчання висвітлювали В. Засенко, А. Колупаєва, В. Синьов, К. Островська, О. Федоренко, В. Шевченко та ін.

Негативною тенденцією сьогодення, на думку В. Бондаря, є стихійність, поспішність, а часом і волюнтаризм узбільшенні кількості учнів, охоплених інклюзивним навчанням, без одночасного створення та впровадження спеціальних програм, спеціальних методик викладання, розширення діапазону спеціальних освітніх послуг та процедур переходу до інклюзії [1]. Відповідно до представлених висновків ефективне здійснення інклюзивного навчання вимагає повної реконструкції системи підготовки та перепідготовки педагогічних фахівців 3 урахуванням парадигм нової філософії спеціальної освіти.

Однак варто зауважити, що зі зростання різновидів освітніх інновацій, зростають і вимоги до професійного рівня підготовки педагогів, які працюють в умовах інклюзії.

Метою статті $\epsilon$ обгрунтування методичних особливостей формування готовності вчителів початкових класів до інноваційної діяльності в умовах інклюзивного навчання та перевірка дієвості запропонованих інновацій шляхом проведення камерного педагогічного експерименту.

Виклад основного матеріалу. Упровадження інклюзивної форми навчання, за Т. Дегтяренко, викликає необхідність змін у підготовці педагогічних кадрів. На думку дослідниці, професійна підготовка майбутніх учителів із метою забезпечення якості освітніх послуг у системі інклюзивної освіти має бути випереджальною [2, с. 93]. При цьому вона повинна містити як теоретичні, так і практичні аспекти, а також передбачати набуття навичок у команді професіоналів. Однак, якщо питанню розвитку фахової компетентності майбутніх фахівців присвячено низку наукових досліджень, то вже практикуючі педагоги мають підвищувати свою кваліфікацію шляхом самоосвіти.

Нами була розглянута структурно-функціональна модель формування готовності вчителів початкових класів до інноваційної діяльності в умовах інклюзивного навчання, що прогнозує шляхи та відтворює засоби підвищення кваліфікації вчителів [3]. Відповідно виникає необхідність обгрунтування методичних особливостей реалізації цієї моделі в закладах загальної середньої освіти (далі - 33CO) та її апробації.

Реалізація розробленої моделі передбачає виконання таких завдань:

- удосконалення навичок інноваційної діяльності в початковій школі, формування авторського стилю викладання;

- удосконалення навичок щодо організації освітнього процесу в умовах інклюзіі;

- удосконалення та відпрацювання навичок самоаналізу та методів нормалізації емоційного стану;

- набуття навичок взаємодії з дітьми з особливими освітніми потребами й усіма учасниками навчального процесу в умовах інклюзії.

Особливості та етапи формування готовності до інноваційної діяльності вчителів початкових класів в умовах інклюзивного навчання в ЗЗСО представлено на рисунку 1.

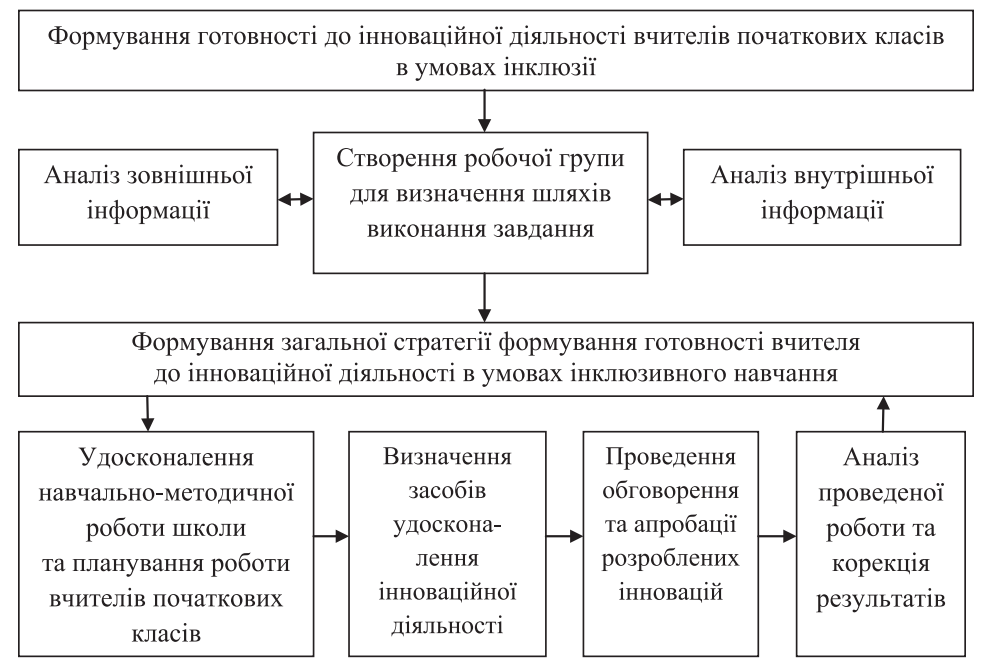

Рис. 1. Етапи формування готовності до інновачійної діяльності вчителів початкових класів в умовах інклюзї̈ у процесі фахової діяльності 
Відповідно до наведених даних (див. рис. 1) основним напрямом діяльності вчителів $є$ забезпечення шляхів удосконалення знань щодо провадження інноваційної діяльності вчителя початкових класів в умовах інклюзії, набуття та відпрацювання ними практичних навичок, удосконалення навичок самоаналізу, подальший розвиток професійної рефлексії.

Для реалізації поставлених завдань було прийняте рішення про внесення змін у навчально-методичну роботи школи в цілому та методичного об'єднання вчителів початкових класів зокрема. Було проаналізовано інформацію щодо методичної діяльності школи (звіти вчителів початкових класів, звіти роботи методичного об'єднання вчителів початкових класів, результати навчально-методичної роботи школи та результати проведення атестації вчителів тощо), визначено ті інноваційні технології, які ефективно використовуються в початкових класах, встановлені методичні особливості їх використання з урахуванням особливостей інклюзивного навчання, а також можливі шляхи поширення інноваційного педагогічного досвіду. Організацію та координацію такої роботи здійснювала створена нами робоча група.

Шляхом опитування було з'ясовано такі недоліки та перешкоди щодо формування готовності вчителів початкових класів до інноваційної діяльності в умовах інклюзивного навчання:

- несприйняття частиною вчителів початкових класів нововведень, несумісність інноваційної діяльності наявним педагогічним досвідом педагогів;

- відсутність координації та методичного супроводу в методичному об'єднанні вчителів початкових класів щодо здійснення інноваційної діяльності;

- суттєве навантаження вчителів початкових класів в умовах інклюзії;

- скептичне ставлення адміністрації до інновацій у початкових класах в умовах інклюзії;

- відсутність мотивації щодо оновлення методів діяльності, небажання змінювати усталений режим навчання учнів, зокрема врахування вимог інклюзивного навчання.

За результатами проведеного теоретичного пошуку було визначено, що в процесі формування готовності

до інноваційної діяльності вчителів початкових класів в умовах інклюзії необхідно конкретизувати цілі, завдання та методи такої діяльності в індивідуальному плані роботи вчителя. Крім того, доцільним є планування здійснення інноваційної діяльності не тільки окремими вчителями, а й спільно. На цьому етапі для контролю такої роботи та координації дій усіх учасників педагогічного експерименту були використанні сучасні інформаційні технологій.

Під час розробки плану педагогічного експерименту щодо визначення ефективності запропонованих інновацій було враховано необхідність:

- вивчення кращого педагогічного досвіду щодо здійснення інноваційної діяльності в умовах інклюзивного навчання для забезпечення мотивації до здійснення інноваційної діяльності;

- методичного супроводу експериментальної роботи вчителями початкових класів шляхом створення інструкцій, рекомендацій, методичних консультацій тощо;

- опанування педагогічними інноваціями не індивідуально, а в процесі групової роботи; апробація розробленого заняття в декількох групах 3 подальшим обговоренням виявлених недоліків та переваг (iз метою забезпечення зворотного зв'язку);

- моніторингу самооцінки теоретичних знань і готовності до інноваційної діяльності вчителів початкових класів в умовах інклюзивного навчання.

Для оцінки дієвості запропонованих інновацій щодо формування готовності вчителів початкової школи до інноваційної діяльності в умовах інклюзивного навчання та з'ясування можливості цілеспрямованого формування досліджуваної готовності було проведено камерний педагогічний експеримент. Рівень готовності визначався за допомогою розроблених тестових анкет та самооцінювання. Процедура діагностування досліджуваної готовності, визначені критерії показники та рівні розглянуті у публікації [4].

В експерименті були задіяні 38 учителів-практиків, слухачів КВНЗ «Вінницька академія неперервної освіти». Результати визначення рівня сформованості досліджуваної готовності на початок камерного експерименту наведені в таблиці 1 .

Таблиия 1

Результати, отримані на початку камерного експерименту

\begin{tabular}{|c|c|c|c|c|c|c|c|c|c|}
\hline \multirow{3}{*}{ Групи } & \multicolumn{8}{|c|}{ Рівні сформованості готовності до інноваційної діяльності } & \multirow{3}{*}{$\begin{array}{l}\text { Кількість } \\
\text { осіб у групі }\end{array}$} \\
\hline & \multicolumn{2}{|c|}{ початковий } & \multicolumn{2}{|c|}{ середній } & \multicolumn{2}{|c|}{ достатній } & \multicolumn{2}{|c|}{ креативний } & \\
\hline & K-Tb & $\%$ & к-Tь & $\%$ & K-Th & $\%$ & K-Tb & $\%$ & \\
\hline КГ & 8 & 44,44 & 7 & 38,89 & 2 & 11,11 & 1 & 5,56 & 18 \\
\hline $\mathbf{E} \Gamma$ & 8 & 40,00 & 8 & 40,00 & 2 & 10,00 & 2 & 10,00 & 20 \\
\hline
\end{tabular}

Для встановлення однорідності контрольної (КГ) та експериментальної груп (ЕГ) скористаємося критерієм $\chi^{2}$ К. Пірсона, який обчислюється за формулою:

$$
\chi_{\text {eмпір. }}^{2}=N \cdot M \cdot \sum_{i=1}^{L} \frac{\left(\frac{n_{i}}{N}-\frac{m_{i}}{M}\right)}{n_{i}+m_{i}},
$$

де $N$ і $M$ - кількість членів контрольної й експериментальної груп; $n_{i}, m_{i}$ - кількість членів контрольної й експериментальної груп, що показали $i$-й рівень готовності до інноваційної діяльності в умовах інклюзивного навчання; $L$ - кількість виділених рівнів готовності до інноваційної діяльності в умовах інклюзивного навчання.
Сформулюємо вихідні гіпотези:

$H_{0}$ - частка вчителів початкових класів, яким притаманний певний рівень готовності до інноваційної діяльності в умовах інклюзивного навчання на початку камерного експерименту в ЕГ не більша ніж у КГ;

$H_{1}$ - частка вчителів початкових класів, яким притаманний певний рівень готовності до інноваційної діяльності в умовах інклюзивного навчання на початку камерного експерименту в ЕГ більша ніж у КГ.

Перевіряємо сформульовані нами гіпотези. Знаходимо значення критерію за формулою (1):

$\chi_{\text {exnip. }}^{2}=18 \cdot 20 \cdot\left[\frac{\left(\frac{8}{18}-\frac{8}{20}\right)^{2}}{8+8}+\frac{\left(\frac{7}{18}-\frac{8}{20}\right)^{2}}{7+8} \frac{\left(\frac{2}{18}-\frac{2}{20}\right)^{2}}{2+2}+\frac{\left(\frac{1}{18}-\frac{2}{20}\right)^{2}}{1+2}\right]=0,3$ 
Відповідно до отриманого результату, критерій Пірсона становить 0,3 . Табличне значення при вихідних умовах для рівня значущості 0,05 дорівнює 7,8.

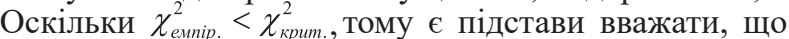
на початок камерного педагогічного експерименту представлені групи однорідні за рівнями сформованості готовності до інноваційної діяльності в умовах інклюзивного навчання.

На завершення камерного експерименту, маємо такі дані (див. табл. 2):

Результати, отримані на момент завершення камерного експерименту

\begin{tabular}{|c|c|c|c|c|c|c|c|c|c|}
\hline \multirow{3}{*}{ Групи } & \multicolumn{8}{|c|}{ Рівні сформованості готовності до інноваційної діяльності } & \multirow{3}{*}{$\begin{array}{c}\text { Кількість } \\
\text { осіб } \\
\text { у групі }\end{array}$} \\
\hline & \multicolumn{2}{|c|}{ початковий } & \multicolumn{2}{|c|}{ середній } & \multicolumn{2}{|c|}{ достатній } & \multicolumn{2}{|c|}{ креативний } & \\
\hline & к-Tb & $\%$ & к-Tь & $\%$ & к-ть & $\%$ & K-Tb & $\%$ & \\
\hline $\mathbf{K \Gamma}$ & 6 & 33,33 & 7 & 38,89 & 3 & 16,67 & 2 & 11,11 & 18 \\
\hline $\mathbf{E \Gamma}$ & 2 & 10,00 & 6 & 30,00 & 8 & 40,00 & 4 & 20,00 & 20 \\
\hline
\end{tabular}

Порівняння структури груп учителів початкових класів щодо рівнів готовності до інноваційної діяльності в умовах інклюзивного навчання (див. рис. 2)

свідчить про отриману позитивну динаміку за результатами камерного експерименту.

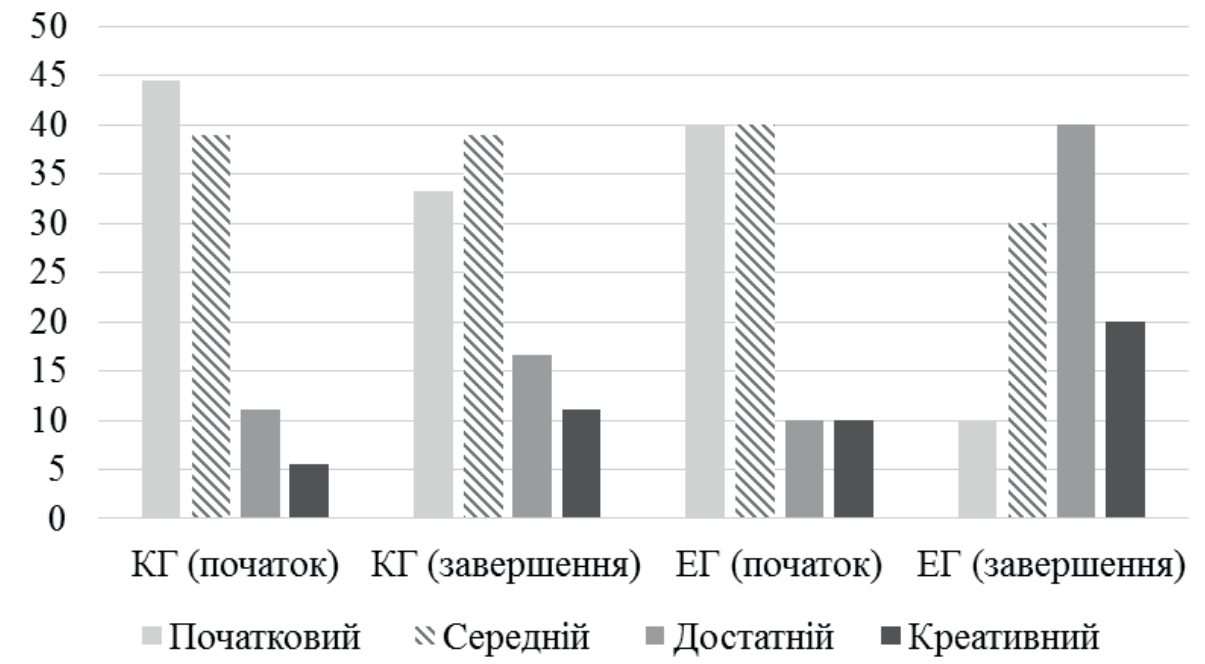

Рис. 2. Динаміка рівнів сформованості готовності до інноваційної діяльності вчителів початкових класів в умовах інклюзивного навчання

Для встановлення наявності впливу запропонованих інновацій, які були реалізовані у процесі камерного експерименту, переведемо шкалу рівнів сформованості готовності до інноваційної діяльності вчителів початкових класів в умовах інклюзивного навчання у дворівневу: «є ефект» (вчителі, які виявили достатній та креативний рівні); «немає ефекту» (вчителі, які виявили початковий і середній рівні). Отримані результати відображено в таблиці 3.

Таблиия 3

Результати, отримані на момент завершення камерного експерименту за дворівневою шкалою

\begin{tabular}{|c|c|c|c|c|c|}
\hline \multirow{3}{*}{ Група } & \multicolumn{4}{|c|}{ Підсумкова оцінка } & \multirow{3}{*}{$\begin{array}{c}\text { Усього } \\
\text { осіб }\end{array}$} \\
\hline & \multicolumn{2}{|c|}{ немас ефекту } & \multicolumn{2}{|c|}{ с ефект } & \\
\hline & K-Tb & $\%$ & K-Tb & $\%$ & \\
\hline $\mathbf{K} \Gamma$ & 13 & 72,22 & 5 & 27,78 & 18 \\
\hline EГ & 8 & 40,00 & 12 & 60,00 & 20 \\
\hline
\end{tabular}

Відповідно до таблиці 3 бачимо, що частка вчителів початкових класів, в яких спостерігається позитивний ефект після впровадження запропонованих інновацій на етапі камерного педагогічного експерименту, становить 60 \% в ЕГ, що на 32,22\% більше ніж у КГ.

Для того, щоб встановити статистичну значущість отриманих даних, використаємо кутове перетворення Фішера $\varphi$. Сформулюємо гіпотези таким чином:

$H_{0}$ - частка вчителів початкових класів, в яких спостерігається позитивний ефект щодо формування досліджуваної готовності після впровадження структурно-функціональної моделі на етапі камерного педагогічного експерименту в експериментальній групі не більша ніж у контрольній;

$H_{1}$ - частка вчителів початкових класів, в яких спостерігається позитивний ефект щодо формування досліджуваної готовності після впровадження структурно-функціональної моделі на етапі камерного педагогічного експерименту в експериментальній групі більша ніж у контрольній.

Перевіряємо сформульовані гіпотези таким чином:

1) отримані відсоткові частки переводимо в радіани за формулою кутового перетворення Фішера:

$\varphi_{1}=2 \arcsin \sqrt{P_{1}}, \varphi_{2}=2 \arcsin \sqrt{P_{2}}$,

де $P_{1}$ та $P_{2}$ - частки, які порівнюються; 
2) обчислюємо значення $\varphi^{*}$-критерію Фішера за формулою:

$$
\varphi^{*}=\left(\varphi_{1}-\varphi_{2}\right) \sqrt{\frac{n_{1} n_{2}}{n_{1}+n_{2}}}
$$

де $n_{1}$ та $n_{2}$ - обсяги вибірок, які досліджуються.

Отримані результати представлено в таблиці 4.

Табличя 4

\section{Результати розрахунків $\varphi$ "-критерію Фішера}

\begin{tabular}{|c|c|c|}
\hline Групи & Розраховане значення $\varphi^{*}$-критерію Фішера & $\begin{array}{c}\text { За рівнем значущості } \\
\mathbf{0 , 0 5}\end{array}$ \\
\hline КГ та ЕГ & 2,09 & 1,64 \\
\hline
\end{tabular}

Відповідно до результатів, наведених у таблищчі 4, підтвердження отримала гіпотеза $H_{1}$, тому констату$є м о$, що частка вчителів початкових класів із достатнім та креативним рівнями сформованості готовності до інноваційної діяльності в умовах інклюзивного навчання в ЕГ більша ніж у КГ і ці дані є статистично значущими.

Висновки. На підставі аналізу наукових досліджень і власних наукових пошуків було обгрунтовано особливості формування готовності вчителів початкових класів до інноваційного навчання в умовах інклюзії та проведено камерний педагогічний експеримент $з$ метою перевірки дієвості запропонованих інновацій.

Використання кутового критерію Фішера для оцінки результатів проведеного експерименту дає підстави вважати підтвердженою альтернативну гіпотезу та зробити висновок про наявність значущої статистичної розбіжності у рівнях готовності вчителів початкових класів до інноваційної діяльності в умовах інклюзивного навчання. Це підтверджує припущення про можливість цілеспрямованого впливу на формування досліджуваної готовності та доцільність проведення повномасштабного педагогічного експерименту.

\section{СПИСОК ВИКОРИСТАНОЇ ЛІТЕРАТУРИ}

1. Бондар В. Освіта дітей з особливими потребами: пошуки та перспективи. URL: http://www.fl-life.com.ua/ inclusion/?page_id=454 (дата звернення: 20.08.2020).

2. Дегтяренко Т. М. До проблеми професійно-прикладної підготовленості випускників вищих навчальних закладів недефектологічних спеціальностей до роботи в системі інклюзивної освіти. Освіта дітей з особливими потребами: від інституціалізаиії до інклюзї : матеріали міжнародного Конгресу зі спеціальної педагогіки, психології та реабілітології : зб. тез доп. / ред. кол. : В. В. Засенко, А. А. Колупаєва, Н. І. Лазаренко, З. П. Ленів. Вінниця : ТОВ фірма «Планер», 2016. С. 92-93.

3. Донець В. Модель формування готовності вчителів початкової школи до інноваційної діяльності в умовах інклюзивного навчання. Нова педагогічна думка : науково-методичний журнал. Рівне : РОІППО, 2020. № 2 (102). С. 107-112.

4. Донець В. Г. Діагностика готовності вчителів початкової школи до інноваційної діяльності в умовах інклюзивного навчання. The scientific heritage. Budapest, 2020. № 46 (4). P. 10-14.

Дата надходження до редакиї: 01.09.2020 p.
УДК 378.14

DOI: 10.37026/2520-6427-2020-103-3-135-139
Олена ПОПАДИЧ,

кандидат педагогічних наук, доцент, дочент кафедри загальної педагогіки та педагогіки вищої школи ДВНЗ «Ужсгородський національний університет»

\section{ПЕДАГОГІЧНІ УМОВИ ПІДГОТОВКИ ВЧИТЕЛІВ ДО ФОРМУВАННЯ ПРАВОВИХ ЗНАНЬ МОЛОДШИХ ШКОЛЯРІВ}

У статті висвітлено вимоги до формування правових знань учнів молодшої школи, яке відбувається иляхом пошуку $і$ відбору елементів иих знань вчителем у змісті всіх навчальних предметів та наступної їх інтеграції у навчальній та позанавчальній діяльності. Важливими аспектами иієї діяльності є врахування вікової спещифіки молодших школярів та необхідність постійного оновлення правової підготовки самого вчителя. Виявлено особливості професійної діяльності вчителя початкових класів та встановлено, щуо оскільки в молодшій школі відсутній окремий навчальний предмет із правознавства, то система правових знань учнів формується фактично за ініціативи вчителя. Обтрунтовано педагогічні умови розробки системи підготовки вчителя до формування правових знань учнів початкової цколи.

Ключові слова: педагогічні умови, вчитель, початкові класи, молодші школярі, правові знання. 